\title{
War is not an exact science
}

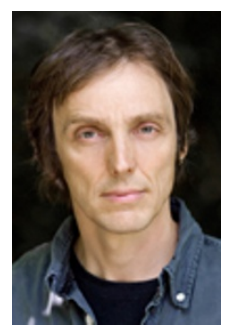

General theories of why we go to war are interesting, says Philip Ball. But they'll never tell the whole story.

Philip Ball

Why are we always fighting wars? That's the sort of question expected from naïve peaceniks, to which historians will wearily reply, "well, it's complicated".

But according to a paper by an international, interdisciplinary team, it isn't that complicated. Their answer is: climate change. David Zhang of the University of Hong Kong and his colleagues show that, in a variety of geographical regions - Europe, China and the arid zones of the Northern Hemisphere — the frequency of war has fluctuated in step with major shifts in climate, particularly during the Little Ice Age from the mid-fifteenth until the mid-nineteenth century 1 .

Cold spells such as this, they say, significantly reduced agricultural production, and as a result food prices soared, food became scarce, and nations went to war. The effect is seemingly huge. "War-peace ... cycles in recent centuries have been driven mainly by long-term climate change," they conclude.

On the one hand, this claim might seem unexceptional, even trivial: food shortages obviously heighten social tensions. On the other hand, it is outrageous: wars, it says, have little to do with ideology, political ambition or sheer greed, but are driven primarily by the weather.

Take, for example, the seventeenth century, when Europe was torn apart by strife. The Thirty Years' War alone, between 1618 and 1648 , killed around a third of the population in the German states. Look at the history books and you'll find this to be the result of a religious conflict resulting from the Martin Luther and Jean Calvin's Reformation, and/or a political power struggle between the Habsburg dynasty and its rivals. Well, forget all that, Zhang and his colleagues seem to be saying: it's all because we were suffering the frigid depths of the Little Ice Age.

\section{World wars}

Historians might be expected to respond to this sort of thing with lofty disdain. You can see their point. The analysis stops at 1900 , and so says nothing about the two most lethal wars in history. The researchers note these took place during an age when economic, technological and institutional changes reduced the impact of agricultural production on world affairs. But can you really say much about the general causes of war if you neglect the global conflicts of the twentieth century?

Clearly, not all wars are about food. Similarly, not all food shortages lead to war. There is, in historical terms, an equally compelling case to be made that the social unrest caused by famine triggers civil war, not the conflict of nation-states.

But more generally, the goal of historical analysis (say most historians) is to explain why particular events happened, not to identify generic social forces that lead to generic consequences.

\section{Generic thinking}

The trend of looking for general causes of war — the 'forces that move nations', as Tolstoy put it — was popular among Marxist historians around the middle of the last century, but has now fallen out of fashion.

Much of it can be traced all the way back to the famous proposal of Thomas Robert Malthus, outlined in his An Essay on the Principles of Population (1789), that population growth cannot continue to rise exponentially forever because it eventually falls foul of the necessarily slower rise in means of production - basically, food runs out. This gloomy vision was also an inspiration to Charles Darwin, who saw that in the wild this competition for limited resources must lead to natural selection. It contributed also to Karl Marx's recipe for socialist revolution.

Zhang and colleagues state explicitly that their findings provide a partial vindication of Malthus. They point out that Malthus did not fully account for the economic pressures and sheer ingenuity that could boost agricultural production when population growth demanded it, but they say that such improvements have their limits, which were exceeded when climate cooling lowered crop yields in Europe and China (see China had more wars in cold weather).

For all their apparently impressive correlation indices, however, much of Zhang's conclusion seems to lean on the coincidence of minimal agricultural production (and maximum food prices), low average temperatures and a peak in the number of wars (and fatalities) during the early to mid-seventeenth century in both Europe and China. The rest of the curves are suggestive, but don't obviously create a compelling historical narrative.

At best, the work sets a challenge: linking climate/agriculture to, for example, the Napoleonic wars. If such a link can't be found in the available historical records, historians might be forgiven for questioning the value of this kind of statistical analysis. 


\section{Search for cause}

The question of what causes war is age-old: Zhang and his colleagues identify it, for example, in Thucydides' History of the Peloponnesian War in the fifth century b.c.

In more modern times, this question motivated the physicist Lewis Fry Richardson between about 1920 and 1950 to plot size against frequency for many recent wars (including the two world wars), to see what patterns might emerge. This revealed a power-law scaling that led to the idea that wars are like landslides, in which small disturbances can trigger events of any scale $\underline{2}, \underline{3}, 4$ (see Don't panic, it might never happen)

Other studies have focused on the cyclical nature of war and peace, as, for example, in ecologist Peter Turchin's 'cliodynamics', which attempts to develop a theory of the expansion and collapse of empires $5, \underline{6}$.

Perhaps most prominent in this arena is an international project called the Correlates of War, which has since 1963 been attempting to understand and quantify the factors that create (and mitigate) international conflict and thus to further the "scientific knowledge about war". Its data sets have been used, for example, in quantitative studies of how warring nations form alliances ${ }^{7}$. They argue rather forcefully against any idea of collapsing the causative factors into a single one, such as climate.

\section{For the future}

What, finally, do Zhang and colleagues have to tell us about future conflict in an anthropogenically warmed world?

At face value, the study might seem to say little, given that it correlates war with cooling events. We do have some reason to think that strong warming could be as detrimental to agriculture as strong cooling, but it's not clear exactly how that would play out, especially in the face of both a more vigorous hydrological cycle and the possibility of more regional droughts. We already know that water availability will become a serious issue for agricultural production, but also that there is a lot that can be done to ameliorate that - for instance improvements in irrigation efficiency.

We'd be wise to greet the provocative conclusions of Zhang et al. with neither naïve acceptance nor cynical dismissal. They do not amount to a theory of history, or of war, and it seems most unlikely that any such things exist. But their paper is at least a warning against a kind of fatalistic solipsism that assumes that all human conflicts are purely the result of human failings.

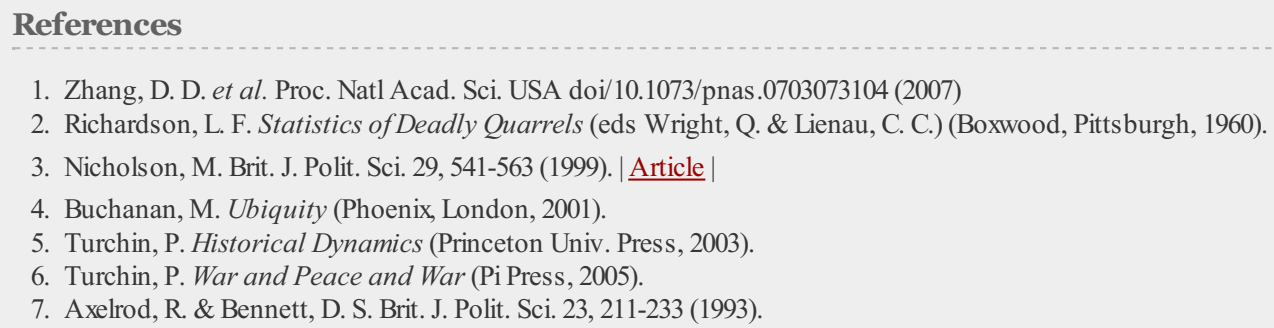

4. Buchanan, M. Ubiquity (Phoenix, London, 2001).

5. Turchin, P. Historical Dynamics (Princeton Univ. Press, 2003).

6. Turchin, P. War and Peace and War (Pi Press, 2005).

7. Axelrod, R. \& Bennett, D. S. Brit. J. Polit. Sci. 23, 211-233 (1993).

\section{Commenting is now closed.}

